\title{
An Evaluation Study on the Effects of Sodium Alginate and Irradiated Sodium Alginate on the Growth of Acokanthera oblongifolia Hochst
}

\author{
Asmaa M. Taha and Mona A. Sorour \\ Antoniades Research Branch Alexandria, Ornamental Plants Research and \\ Landscape Gardening Department, Horticulture Research Institute, ARC, Egypt.
}

\begin{abstract}
Two experiments were carried out at Antoniades Research Branch, Ornamental Plants Research and Landscape Gardening Department Horticulture Research Institute, A.R.C. Alexandria, Egypt during the two successive seasons 2014/2015 and 2015/2016 to investigate the effect of sodium alginate (SA) and irradiated sodium alginate (ISA) on seed germination and the growth of Acokanthera plants. The first experiment was to investigate the effects of (SA and ISA) on seed germination; the seeds of Acokanthera were soaked in seven solution $50 \mathrm{ppm}$ SA and different concentrations of ISA [0.0 (distilled water), 50, 75, 100, 125 and $150 \mathrm{ppm}$ ] for 24 hours, The treatment 50 and $125 \mathrm{ppm}$ ISA significantly improved germination rate and percentage. The second experiment was to study the effect of the foliar spray of SA and ISA on Acokanthera plants with the same concentrations used in the first experiment the results showed that all treatment of ISA caused an increment in most studied characters and the treatment $50 \mathrm{ppm}$ ISA caused the highest significant increase in all vegetative growth parameters ( plant height, numbers of leaves, fresh weight, dry weight, leave area and stem diameter), root characters (root volume and root dry weight), chlorophyll and carbohydrate content.
\end{abstract}

Key words: Acokanthera oblongifolia, Sodium Alginate (SA), irradiated sodium alginate (ISA).

\section{INTRODUCTION}

Acokanthera oblongifolia Hochst. (Synonyms Acokanthera spectabilis, Carissa oblongifolia, Toxicophloea spectabilis) common names (Bushman's poison, poison bush, poison tree and a winter sweet) belongs to family Apocynaceae. It is a medium to a large woody shrub with an attractive hard dark green leaves. Clusters of pinkish white, sweetly scented flowers are borne in late winter and spring and they are followed by a large plum colored berry-like fruits which relished by birds. The Bushman's poison is a hardly drought and frost resistant evergreen shrub that tolerates full sun or shade and also does well as a container plant. (Arnold \& De wet 1993 and Pooley 1993).

Sodium alginate is a natural polysaccharide. It is the sodium salt of alginic acid. Its formula is $\mathrm{NaC}_{6} \mathrm{H}_{7} \mathrm{O}_{6}$ which is derived from the cell walls of brown algae. It can be degraded from macromolecules to micromolecules which is known as oligomers by using gamma irradiation (Luan et al., 2003). This oligomers are used in the biomedical and agriculture field (El-Mohdy, 2017). Irradiated sodium alginate has many physiological and biological activities on plants (Mollah et al., 2009). These activities include promotion of plant growth, seed germination, shoot elongation and root growth (Yonemoto et al., 1993; Natsume et al., 1994; Hu et al., 2004).

The aim of this study was to investigate the effects of sodium alginate (SA) and irradiated sodium alginate (ISA) on improving seed germination and growth of Acokanthera oblongifolia plants.

\section{MATERIAL AND METHODS}

The present study was carried out during two successive seasons of 2014/2015 and 2015/2016 at Antoniades Research Branch, Ornamental Plants Research and Landscape Gardening Department. Horticultural Research Institute, A.R.C. Alexandria, Egypt.

Two experiments were done in this study; the first one was to investigate the effect of sodium alginate (SA) and irradiated sodium alginate (ISA) on seed germination of Acokanthera plants and the second one to investigate the effect of foliar spray of SA and ISA on the growth of Acokanthera seedlings.

Gamma rays which are used for this experiment were generated from Cobalt-60 source at the National Center for Radiation Research and Technology, Atomic Energy Authority Nasr City, Cairo, Egypt. SA sample was irradiated with 520 Kilo Gray at the rate dose 2Kilo Gray (K Gy) gamma rays. It was sealed in a glass vial with atmospheric air. $50 \mathrm{ppm}$ un-irradiated sodium alginate (SA) and different concentrations of irradiated sodium alginate (ISA). [ 0.0 (distilled water), 50, 75, 100, 125 and $150 \mathrm{ppm}]$ were finally prepared using distilled water.

The first experiment: The effect of sodium alginate (SA) and irradiated sodium alginate (ISA) on seed germination of Acokanthera plants:

On the $20^{\text {th }}$ of Mars 2015 thirty two seeds of Acokanthera plant were soaked for 24 hours in seven solutions; deionized water (control), $(50 \mathrm{ppm}$ (SA) and $[50,75,100,125$ and 150 ppm ISA]. The 
seeds were planted in a germination tray containing sand soil one tray for each treatment.

The following data were recorded:

1- Germination rate (GR)

It was calculated according to the following formula (Mahmoud, 2013):

Germination rate $(\mathrm{GR})=$

$$
\frac{a+(a+b)+(a+b+c)+\cdots+(a+b+c+m)}{n(a+b+c+m)}
$$

Where $a, b, c$ are the number of germinated seeds in the first, second and third count, $\mathrm{m}$ is the number of germinated seeds in the final count, $n$ is the number of counts.

2- Germination percentage (\%):

It was calculated according to the following formula (Mahmoud, 2013):

Germination $\quad$ percentage $(\%)$
$\frac{\text { number of germinated seeds }}{\text { total seed number }} \times 100$

This percentage was calculated after 60 days of planting.

The second experiment: The effect of sodium alginate (SA) and irradiated sodium alginate (ISA) on the growth of Acokanthera plants:

On $18^{\text {th }}$ and $23^{\text {rd }}$ of June on the two seasons 2014/2015 and 2015/2016, respectively. Nine weeks seedlings of Acokanthera plants (2 pairs of leaves) were planted in $14 \mathrm{~cm}$ plastic pots containing a mixture of sandy and clay soil at the ratio of ( $1: 1$ by volume)

After six days of planting the seedling were sprayed with hand sprayer with the following treatments: Deionized water (control), 50 ppm SA, $50,75,100,125$ and $150 \mathrm{ppm}$ ISA. The treatment repeated weekly for five months. On November 2014 and 2015 in the first and second season; respectively the treatment of ISA stopped for four months. On March 2015 and 2016 in the first and second season the foliar spray of ISA continued weekly for four months. The experiment terminated on the first of June on 2015 and 2016 for the first and second season respectively.

The following data were recorded:

1-Relative plant height growth rate $\left(\mathrm{cm} \mathrm{month}{ }^{-1}\right)$ : It was calculated according to the formula of John et al., 2006

Relative height growth rate $=\frac{\ln \mathrm{H} 2-\ln \mathrm{H} 1}{T 2-T 1}$

Where $\mathrm{H} 2$ is the plant height at the end of the experiment and $\mathrm{H} 1$ is the plant height at the beginning of experiment. $\mathrm{T} 1$ is the first time and $\mathrm{T} 2$ second time.

2- Vegetative growth characters: Plant height (cm), number of leaves /plant, vegetative growth fresh weight $(\mathrm{g})$, vegetative growth dry weight $(\mathrm{g})$, leaves area $\left(\mathrm{cm}^{2}\right)$ and stem diameter (mm).
3- Root characters root volume $\left(\mathrm{cm}^{3}\right)$ and root dry weight $(\mathrm{g})$

4- Chemical analysis: Chlorophyll a and b content (mg/g fresh weight) was determined according to Moran, 1982, total carbohydrate content (\%) in the leaves of the plant according to Hedge and Hofreiter 1962 and anthocyanin was determined by placing leaf discs $\left(0.9 \mathrm{~cm}^{2}\right.$ total $)$ in $3 \mathrm{ml}$ acidified methanol with $10 \mathrm{ml}$ concentrated $\mathrm{HCL} / \mathrm{L}$ for 2 days at $4{ }^{\circ} \mathrm{C}$. Light absorbance of the methanol extracts were determined at 530 and $657 \mathrm{~nm}$ Anthocyanin concentration was calculated using the following formula of Mancinelli et al.,(1988): Ant $=$ A $530-0.25$ (A 657).

Statistical Analysis

The experiment layout was designed to provide randomized complete blocks design (RCBD) which is containing three replicates, each replicate contained seven treatments. Three plants were used as a plot for each treatment in each replicate. The means of the individual factors were compared by L.S.D. at $5 \%$ level of probability according to Snedecor and Cochran, 1989.

\section{RESULTS}

The first experiment: Effect of SA and ISA on seed germination of Acokanthera plants:

Figure (1) illustrated that highest germination rate was obtained after soaking the seeds in 50 and 125 ppm ISA, they are both more than 0.5 For germination rate after 60 days of planting. Figure (2) showed that all treatments caused an increment in germination percentage compared to control plant which was $59.38 \%$ and the highest germination percentage was obtained by seed soaking in 50, 125 and $150 \mathrm{ppm}$ ISA which were more than $90 \%$.

The second experiment: Effect of SA and ISA on the growth of Acokanthera plants:

\section{1-Relative height growth rate}

Figure (3 and 4) illustrated that the highest relative height growth rate was obtained by application 50 ppm ISA which was $0.102 \mathrm{~cm}^{\text {month }}$ ${ }^{1}$ in the first season and more than 0.092 in the second one.

2-Vegetative growth parameters

Data in Table (1) showed that there was a significant increase in all studied vegetative growth parameters after application of all ISA treatments and the spray of $50 \mathrm{ppm}$ un-irradiated sodium alginate resulted in promotive effects on all vegetative growth parameters.

The highest plants were obtained after application of ISA at 75 ppm by $50.90 \%$ and 78.94 $\%$ as compared to control in both seasons respectively. An exceed of number of leaves by 38.3 $\%$ and $97.25 \%$ in the first and second season respectively compared to control plants was obtained by foliar spray of $50 \mathrm{ppm}$ ISA, this 
treatment caused the heaviest fresh weight by $82.31 \%$ and $98.88 \%$ and heaviest dry weight by $102.3 \%$ and $186.13 \%$ compared to control in both season respectively. For leaves area the treatment 75 ppm ISA caused the highest increase by $82.86 \%$ in the first season and the treatment by $50 \mathrm{ppm}$ ISA
$108.8 \%$ in the second one compared to control. Also, the highest increase in stem diameter was obtained by the treatment 75 ppm ISA by $22.56 \%$ and the treatment 50 ppm ISA by $43.12 \%$ in the second season compared to control.

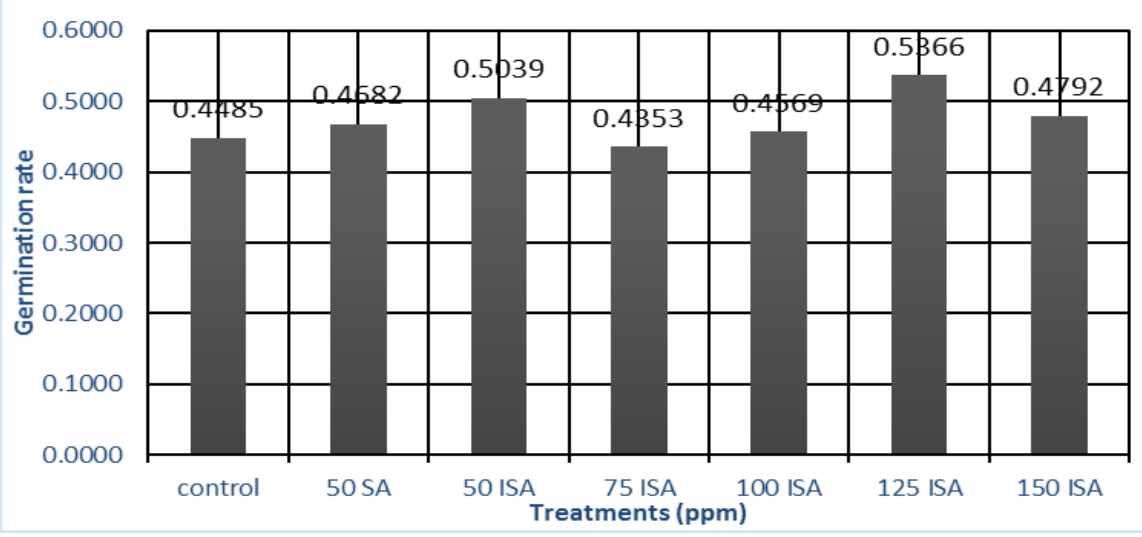

Figure 1: Effect of different treatments of sodium alginate and irradiated sodium alginate on germination rate of Acokanthera oblongifolia Hochst.

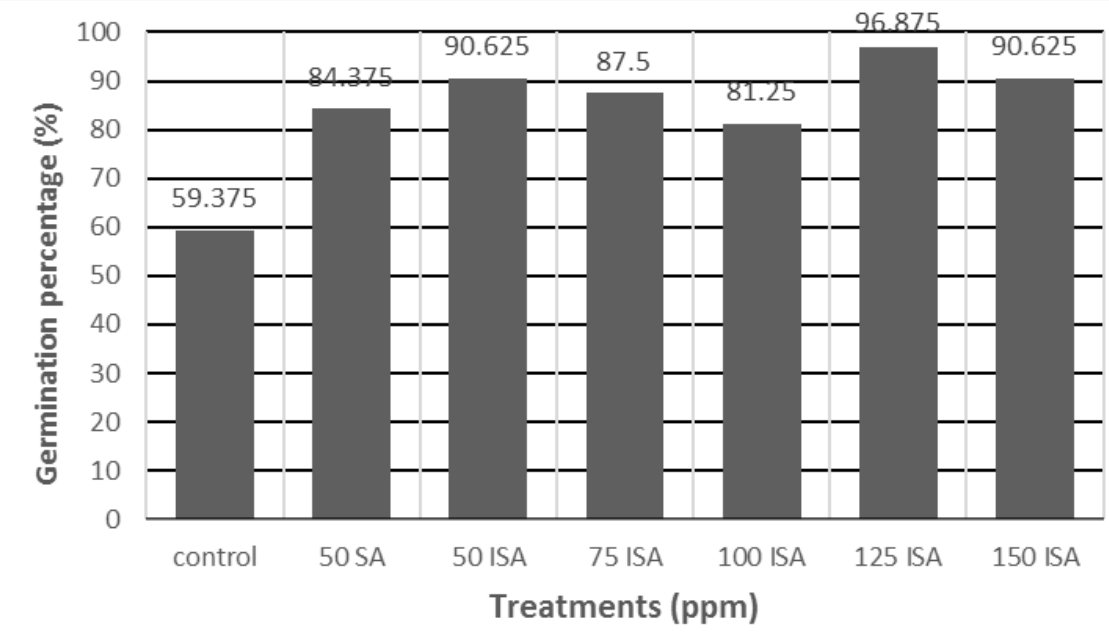

Figure 2: Effect of different treatments of sodium alginate and irradiated sodium alginate on germination percentage of Acokanthera oblongifolia Hochst.

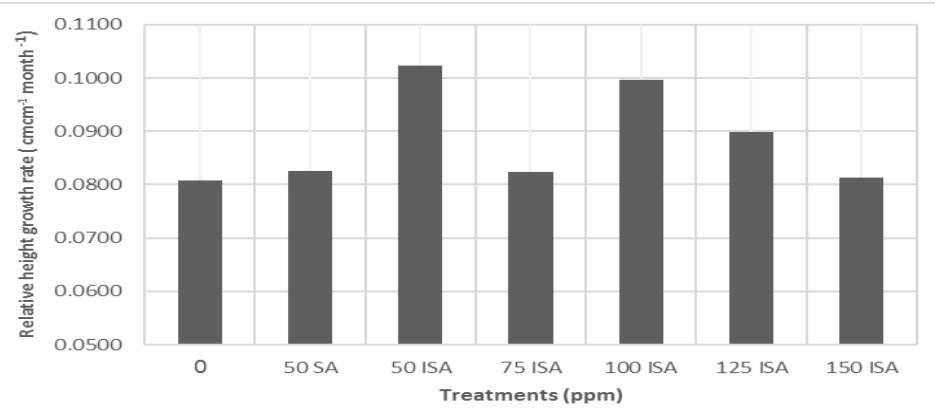

Figure 3: Effect different treatments of sodium alginate and irradiated sodium alginate on relative height growth rate of Acokanthera oblongifolia Hochst during the season of (2015). 


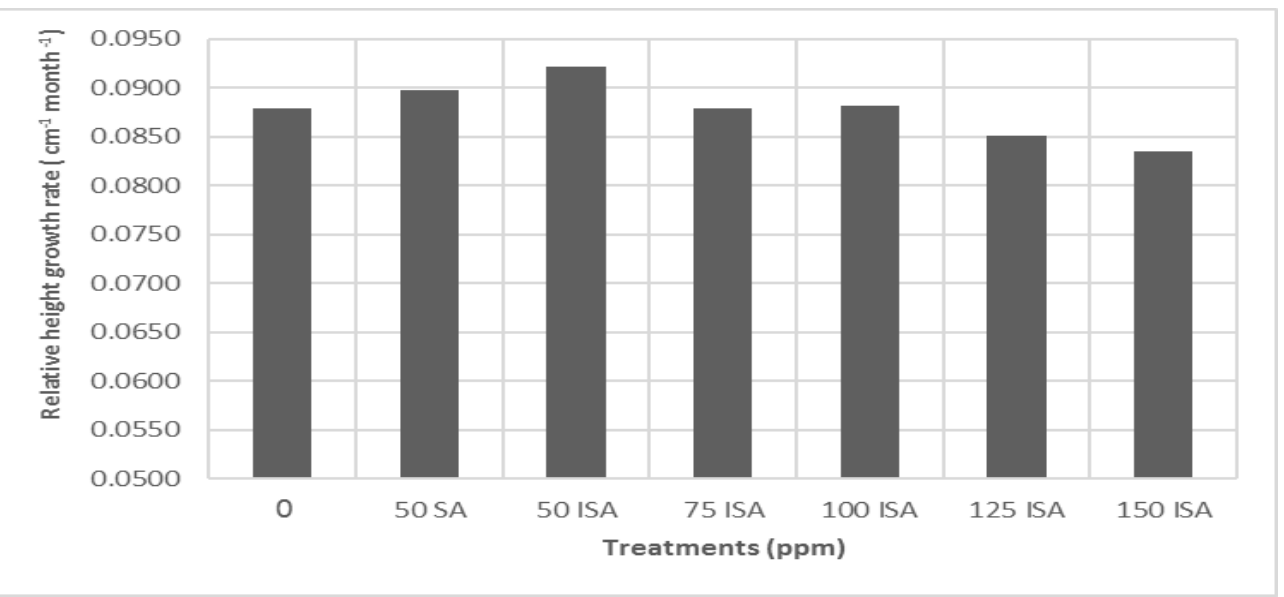

Figure 4: Effect different treatments of sodium alginate and irradiated sodium alginate on relative height growth rate of Acokanthera oblongifolia Hochst during the season of (2016).

Table 1: Means of plant height (cm), leaves number, plant fresh weight (gm.), plant dry weight (gm.), leave area $\left(\mathrm{cm}^{2}\right)$ and stem diameter $(\mathrm{mm})$ of Acokanthera oblongifolia Hochst. as influenced by $50 \mathrm{ppm}$ SA and various concentrations of ISA during the two seasons of 2015 and 2016.

\begin{tabular}{|c|c|c|c|c|c|c|c|c|c|c|c|c|}
\hline \multirow[t]{2}{*}{$\begin{array}{l}\text { Treatmen } \\
\text { ts }(p p m)\end{array}$} & \multicolumn{2}{|c|}{$\begin{array}{c}\text { Plant height } \\
\text { (cm) }\end{array}$} & \multicolumn{2}{|c|}{ Leaves number } & \multicolumn{2}{|c|}{$\begin{array}{c}\text { Plant fresh } \\
\text { weight (gm.) }\end{array}$} & \multicolumn{2}{|c|}{$\begin{array}{c}\text { Plant dry } \\
\text { weight (gm.) }\end{array}$} & \multicolumn{2}{|c|}{$\begin{array}{c}\text { Leave area } \\
\left(\mathrm{cm}^{2}\right)\end{array}$} & \multicolumn{2}{|c|}{$\begin{array}{c}\text { Stem diameter } \\
(\mathrm{mm})\end{array}$} \\
\hline & 2015 & 2016 & 2015 & 2016 & 2015 & 2016 & 2015 & 2016 & 2015 & 2016 & 2015 & 2016 \\
\hline Control & $12.81 \mathrm{~d}$ & $12.25 \mathrm{c}$ & $10.00 \mathrm{f}$ & $8.00 \mathrm{f}$ & $4.07 \mathrm{c}$ & $5.38 \mathrm{~d}$ & $1.72 \mathrm{c}$ & $1.37 \mathrm{~d}$ & $8.75 \mathrm{~d}$ & $11.56 \mathrm{c}$ & $1.64 \mathrm{~b}$ & $1.60 \mathrm{bc}$ \\
\hline $50 \mathrm{SA}$ & $14.86 \mathrm{~cd}$ & $15.17 \mathrm{~b}$ & $11.11 \mathrm{cdf}$ & $11.27 \mathrm{~cd}$ & $5.42 \mathrm{bc}$ & $6.22 \mathrm{~cd}$ & $2.03 \mathrm{c}$ & $1.93 \mathrm{~cd}$ & $11.23 \mathrm{~cd}$ & $15.00 \mathrm{bc}$ & $1.76 \mathrm{~b}$ & $1.78 \mathrm{bc}$ \\
\hline 50 ISA & $19.17 \mathrm{ab}$ & $20.83 a$ & $13.83 \mathrm{a}$ & $15.78 \mathrm{a}$ & $7.42 \mathrm{a}$ & $10.70 \mathrm{a}$ & $3.48 \mathrm{a}$ & $3.92 \mathrm{a}$ & $14.37 \mathrm{ab}$ & $24.14 \mathrm{a}$ & $1.97 \mathrm{a}$ & $2.29 \mathrm{a}$ \\
\hline 75 ISA & $19.33 \mathrm{a}$ & $21.92 \mathrm{a}$ & $13.45 \mathrm{ab}$ & $13.56 \mathrm{~b}$ & $7.46 a$ & $8.30 \mathrm{~b}$ & $3.47 \mathrm{a}$ & $2.62 b$ & $16.00 \mathrm{a}$ & $17.89 b$ & $2.01 \mathrm{a}$ & $1.92 \mathrm{~b}$ \\
\hline 100 ISA & $18.08 \mathrm{ab}$ & $20.83 a$ & $12.22 b c$ & $12.11 b c$ & $6.62 \mathrm{ab}$ & $7.41 b c$ & $2.82 b$ & $2.33 b c$ & $12.75 b c$ & $15.57 \mathrm{bc}$ & $1.94 \mathrm{a}$ & $1.91 \mathrm{~b}$ \\
\hline 125 ISA & $17.89 \mathrm{ab}$ & $19.92 \mathrm{a}$ & $11.78 \mathrm{~cd}$ & $10.33 \mathrm{df}$ & $6.59 \mathrm{ab}$ & $7.21 \mathrm{bc}$ & $2.60 \mathrm{~b}$ & $2.10 \mathrm{c}$ & $13.61 \mathrm{abc}$ & $16.97 \mathrm{~b}$ & $1.72 \mathrm{~b}$ & $1.89 \mathrm{~b}$ \\
\hline 150 ISA & $16.89 b c$ & $19.33 \mathrm{a}$ & $10.44 \mathrm{df}$ & $10.06 \mathrm{df}$ & $5.64 \mathrm{bc}$ & $6.99 \mathrm{~cd}$ & $2.12 \mathrm{c}$ & $2.04 \mathrm{c}$ & $12.60 \mathrm{bc}$ & $16.27 b$ & $1.67 \mathrm{~b}$ & $1.84 \mathrm{~b}$ \\
\hline $\begin{array}{l}\text { L.S.D.at } \\
0.05\end{array}$ & 2.32 & 2.28 & 1.29 & 1.63 & 1.62 & 1.28 & 0.46 & 0.47 & 2.57 & 4.19 & 0.17 & 0.18 \\
\hline
\end{tabular}

L.S.D. $=$ Least significant different at 0.05 level of probability

\section{3- Roots characteristics:}

Data in Table (2) cleared that all ISA treatments caused a significant increase in roots volume and dry weight. Also, there was no significant difference between the spray of $50 \mathrm{ppm}$ un-irradiated sodium alginate and control.
The highest increase in root volume was obtained by application of 50 ppm ISA by $147.71 \%$ and $111.11 \%$ compared to control in the first and second season respectively. Also foliar spray of 50 ppm ISA caused the heaviest root dry weight by $97.42 \%$ and $102.5 \%$ in both seasons respectively compared to control.

Table 2: Root volume $\left(\mathrm{cm}^{3}\right)$ and Root dry weight (g) of Acokanthera oblongifolia Hochst. as influenced by $50 \mathrm{ppm}$ SA and various concentrations of ISA during the two seasons of 2015 and 2016.

\begin{tabular}{lcccc}
\hline \multirow{2}{*}{ Treatments $(\mathbf{p p m})$} & \multicolumn{2}{c}{ Root volume $\left.\mathbf{( c m}^{\mathbf{3}}\right)$} & \multicolumn{2}{c}{ Root dry weight $\mathbf{( g )}$} \\
\cline { 2 - 5 } & $\mathbf{2 0 1 5}$ & $\mathbf{2 0 1 6}$ & $\mathbf{2 0 1 5}$ & $\mathbf{2 0 1 6}$ \\
\hline Control & $3.50 \mathrm{e}$ & $4.50 \mathrm{e}$ & $2.33 \mathrm{c}$ & $2.00 \mathrm{e}$ \\
\hline 50 SA & $4.50 \mathrm{de}$ & $6.00 \mathrm{de}$ & $2.68 \mathrm{bc}$ & $2.21 \mathrm{de}$ \\
\hline 50 ISA & $8.67 \mathrm{a}$ & $9.50 \mathrm{a}$ & $4.60 \mathrm{a}$ & $4.05 \mathrm{a}$ \\
\hline 75 ISA & $7.83 \mathrm{ab}$ & $8.50 \mathrm{ab}$ & $4.30 \mathrm{a}$ & $3.68 \mathrm{ab}$ \\
\hline 100 ISA & $7.42 \mathrm{abc}$ & $7.50 \mathrm{bc}$ & $3.24 \mathrm{~b}$ & $3.27 \mathrm{bc}$ \\
\hline 125 ISA & $6.33 \mathrm{bcd}$ & $7.00 \mathrm{~cd}$ & $2.92 \mathrm{bc}$ & $2.70 \mathrm{~cd}$ \\
\hline 150 ISA & $5.58 \mathrm{~cd}$ & $6.33 \mathrm{cde}$ & $2.73 \mathrm{bc}$ & $2.40 \mathrm{de}$ \\
\hline L.S.D.at 0.05 & 1.96 & 1.31 & 0.86 & 0.67 \\
\hline
\end{tabular}

L.S.D. $=$ Least significant different at 0.05 level of probability 
Table 3: Means of chlorophyll A (mg/g fresh weight), chlorophyll B (mg/g fresh weight), anthocyanin and total carbohydrate (\%) of Acokanthera oblongifolia Hochst. as influenced by 50 ppm SA and various concentrations of ISA during the two seasons of 2015 and 2016.

\begin{tabular}{lcccccccc}
\hline \multirow{2}{*}{ Treatments (ppm) } & \multicolumn{2}{c}{$\begin{array}{c}\text { Chlorophyll a } \\
\text { (mg/g fresh } \\
\text { weight }\end{array}$} & \multicolumn{2}{c}{$\begin{array}{c}\text { Chlorophyll b } \\
\text { (mg/g fresh } \\
\text { weight) }\end{array}$} & \multicolumn{2}{c}{$\begin{array}{c}\text { Total } \\
\text { Carbohydrate } \\
(\mathbf{\%})\end{array}$} & $\begin{array}{c}\text { Anthocyanin } \\
\text { Content }\end{array}$ \\
\cline { 2 - 11 } & $\mathbf{2 0 1 5}$ & $\mathbf{2 0 1 6}$ & $\mathbf{2 0 1 5}$ & $\mathbf{2 0 1 6}$ & $\mathbf{2 0 1 5}$ & $\mathbf{2 0 1 6}$ & $\mathbf{2 0 1 5}$ & $\mathbf{2 0 1 6}$ \\
\hline Control & $0.29 \mathrm{~b}$ & $0.34 \mathrm{~d}$ & $0.11 \mathrm{c}$ & $0.14 \mathrm{~d}$ & $5.58 \mathrm{c}$ & $6.01 \mathrm{c}$ & 0.088 & 0.113 \\
\hline 50 SA & $0.31 \mathrm{~b}$ & $0.50 \mathrm{c}$ & $0.14 \mathrm{~b}$ & $0.18 \mathrm{~cd}$ & $6.71 \mathrm{bc}$ & $6.71 \mathrm{bc}$ & 0.085 & 0.108 \\
\hline 50 ISA & $0.65 \mathrm{a}$ & $0.86 \mathrm{a}$ & $0.19 \mathrm{a}$ & $0.31 \mathrm{a}$ & $8.95 \mathrm{a}$ & $9.07 \mathrm{a}$ & 0.078 & 0.088 \\
\hline 75 ISA & $0.65 \mathrm{a}$ & $0.68 \mathrm{~b}$ & $0.19 \mathrm{a}$ & $0.28 \mathrm{ab}$ & $8.06 \mathrm{ab}$ & $8.71 \mathrm{a}$ & 0.069 & 0.071 \\
\hline 100 ISA & $0.60 \mathrm{a}$ & $0.68 \mathrm{~b}$ & $0.18 \mathrm{a}$ & $0.27 \mathrm{ab}$ & $7.76 \mathrm{ab}$ & $7.77 \mathrm{ab}$ & 0.083 & 0.069 \\
\hline 125 ISA & $0.57 \mathrm{a}$ & $0.68 \mathrm{~b}$ & $0.16 \mathrm{a}$ & $0.23 \mathrm{bc}$ & $7.72 \mathrm{ab}$ & $7.75 \mathrm{abc}$ & 0.078 & 0.072 \\
\hline 150 ISA & $0.56 \mathrm{a}$ & $0.67 \mathrm{~b}$ & $0.16 \mathrm{a}$ & $0.16 \mathrm{~cd}$ & $6.52 \mathrm{bc}$ & $7.68 \mathrm{abc}$ & 0.085 & 0.078 \\
\hline L.S.D.at .05 & 0.11 & 0.09 & 0.04 & 0.07 & 1.52 & 1.75 & N.S. & N.S. \\
\hline L.S.D. = Least significant different at 0.05 level of probability & & & & &
\end{tabular}

\section{4- Chemical analysis.}

Data in Table (3) showed that the highest increase in chlorophyll a and chlorophyll b content was obtained after foliar spray with 50 ppm ISA.

Application of ISA at 50 and $75 \mathrm{ppm}$ in the first season caused the highest increase of chlorophyll a by $124.14 \%$ and the treatment $50 \mathrm{ppm}$ ISA in the second season caused the highest increase by 152.9 $\%$ compared to control plants. For chlorophyll b these treatments resulted in the same trend as 50 and $75 \mathrm{ppm}$ of ISA caused the highest increase by 72.2 $\%$ in the first season and the treatment of $50 \mathrm{ppm}$ by $121.42 \%$ in the second season compared with control.

For total carbohydrate content, the highest significant increase was obtained by foliar spray of 50 ppm ISA by $60.39 \%$ and $50.9 \%$ compared with the control in the first and second season respectively. For Anthocyanin content, there was insignificant difference between treatments.

\section{DISCUSSION}

Oligomers obtained from sodium alginate acted like endogenous growth elicitor and worked as signal molecules to trigger the synthesis of different enzymes and activate various plant responses, exploiting the gene expression as like the case of Cadmium stress (Ma et al., 2010) The ability of oligosaccharides to induce physiological processes in plants depends on the specific structure and size of it (Darvill et al., 1992).

Application of gel permeation chromatography (GPC) study revealed that there was a low molecular weight of fraction ISA (Naeem et al., 2012). Which may be the cause of its response on plant growth. Nevertheless, more investigations are needed to study how ISA stimulate plant growth.

The results of this study showed that application of foliar spray of ISA resulted in enhancement of all studied characters this results are in harmony with those obtained by Aftab et al.,
2011 on Artemisia, Khan et al., 2011 on opium and Sarfaraz et al., 2011 on fennel and Naeem et al., 2012, 2014 on mint. Application of ISA caused a significant increase in leaf area which may be affect in gaining more sunlight to use extra $\mathrm{CO}_{2}$ to increase photosynthesis and accumulation of more dry matter. There was a significant increase in root characteristics and shoot elongation which may be attributed to the growth promoting the effect of ISA (El- Rehim, 2006; Naeem et al., 2014).

\section{CONCLUSION}

Soaking seeds of of Acokanthera oblongifolia Hochst in $50 \mathrm{ppm}$ irradiated sodium alginate for 24 hours increase germination rate and percentage. Also irradiated sodium alginate can be used as a foliar spray on Acokanthera seedling at $50 \mathrm{ppm}$. This treatment caused an increase in vegetative growth parameters, root characteristics, chlorophyll content and total carbohydrate content. More studies are needed to know how ISA stimulate seed germination and plant growth.

\section{REFERENCES}

Aftab, T.;M. M. A. Khan; M. Idrees;M. Naeem;M. Moinuddin and N. Hashmi. (2011). Enhancing the growth, photosynthetic capacity and artemisinin content in Artemisia annua L. by irradiated sodium alginate. Radiation Physics and Chemistry, 80: 833-836

Arnold, T.H. and B.C. De Wet (1993). Plants of southern Africa: names and distribution. Memoirs of the Botanical Survey of South Africa No. 62. National Botanical Institute, Pretoria.

Darvill, A.; C. Auger.; C. Bergman; R.W. Carlson.; J.J. Cheong and S. Eberhard, (1992). Oligosaccharins-oligosaccharides that regulate growth, development and defense response in plants. Glycobiology, 2: 181-198. 
El-Mohdy, H.L.A. (2017). Radiation-induced degradation of sodium alginate and its plant growth promotion effect. Arabian Journal of Chemistry. 10, S431-S438.

El-Rehim, A. H. A. (2006). Characterization and possible agricultural application of polyacrylamide/sodium alginate cross-linked hydrogels prepared by ionizing radiation. J. Applied Polymer Science, 101: 3572-3580.

Hedge, J.E. and B.T. Hofreiter (1962). Carbohydrate Chemistry, 17 (Eds. Whistler R.L. and Be Miller, J.N.), Academic Press, New York. 356378.

Hu, X, X. Jiang ; H. Hwang; S. Liu and H. Guan (2004). Promotive effects of alginate - derived oligosaccharide on maize seed germination. J. Appl. Phycol., 16:73-76.

John, P.A.;Asia Khamzina and W. Martin (2006). The analyses of physiological and morphological attributes of 10 tree species for early determination of their suitability to afforest degraded landscapes .The Aral Sea Basin of Uzbekistan Forest Ecology and Management 221: 249-259

Khan, Z. A.; M.M. A.Khan; T. Aftab;T. M. Idrees and $M$. Naeem, (2011). Influence of alginate oligosaccharides on growth, yield and alkaloid production of opium poppy (Papaver somniferum L.). Frontiers of Agriculture in China, 5, 122: 127.

Luan, L.Q.; N.Q .Hien; N. Nagasawa; T. Kume, F. Yoshii and T.M. Nakanishi (2003). Biological effect of radiation-degraded alginate on flower plants in tissue culture, Biotechnol. Appl. Biochem., 38: 283 - 288.

Ma, L. J.; X. M. Li;N. Bu and N. Li (2010). An alginate-derived oligosaccharide enhanced wheat tolerance to cadmium stress. Plant Growth Regulation, 62: 71 -76.

Mancinelli, A.L.; A. M. Hoff and M. Cottrell (1988). Anthocyanin production in Chl-rich and Chl-poor seedlings. Plant Physiol., 86: 652-654.

Mollah. MZI; M.A., Khan and R.A., Khan (2009). Effect of gamma irradiated sodium alginate on red amaranth (Amaranthus cruentus L.) as growth promoter, Radiat. Phys. Chem., 78:6164.
Mahmoud, A.E.K (2013). Vegetable plants physiology. El-Maaref Publishers Alexandria

Moran, R. (1982). Formula determination of chlorophyll pigment extracted with $\mathrm{N}, \mathrm{N}$ diethyl formamide, Plant Physiol., 69: 1376-1381.

Naeem, M.; M. Idrees; T. Aftab; T. Khan; M. M. A.; Moinuddin, and L. Varshney. (2012). Depolymerized carrageenan enhances physiological activities and menthol production in Mentha arvensis L. Carbohydrate Polymer, 87, 1211-1218

Naeem, M.; M. Idrees; T. Aftab; M. Alam; M. Khan and M. A. Moinuddin,. (2014). Employing depolymerized sodium alginate, triacontanol and 28-homobrassinolide in enhancing physiological activities, production of essential oil and active components in Mentha arvensis L. Industrial Crops and Products, 55: 272-279

Natsume, M; Y. Kamao; M. Hirayan and J. Adachi (1994). Isolation and characterization of alginate derived oligosaccharides with root growth promoting activities. Carbohy. Res., 258: 187-197.

Pooley. E (1993). The complete field guide to Trees of Natal, Zululand \& Transkei. Natal Flora Publications Trust: Durban, South Africa.

Sarfaraz, A.; M. Naeem; S. Nasir; S. M. Idrees; T. Atab, and N. Hashmi (2011). An evaluation of the effects of irradiated sodium alginate on the growth, physiological activity and essential oil production of fennel (Foeniculum vulgare Mill.). Journal of Medicinal Plants Research, 5, 15: 21

Snedecor, G. W. and W. Cochran (1989). Statistical Methods, $8^{\text {th }}$ Ed. Iowa State University Press.

Yonemoto, Y.; H. Tanaka; T. Yamashita; N. Kitabatake; Y. Ishida, A. Kimura and K. Murata (1993). Promotion of germination and shoot elongation of some plants by alginate oligomers prepared with bacterial alginate lyase. J. Ferment. Bioengin., 75: 68-70. 


\section{الملخص العربى}

دراسة استخدام الصوديوم إلجينات والصوديوم إلجينات المشعع على نمو نباتات الكوكنتا

$$
\begin{aligned}
& \text { اسماء محمد طه، منى عبد الحميد سرور } \\
& \text { فرع بحوث نباتات الزينة بأنطونبادس - الإسكندرية } \\
& \text { قسم بحوث الزينة وتتسيق الحدائق- معهد بحوث البساتين - مركز البحوث الزراعية }
\end{aligned}
$$

اجريت تجربتين في فرع بحوث نباتات الزينة بأنطونيادس، معه بحوث البساتين، وزارة

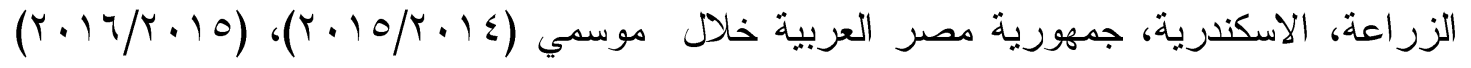
لار اسة تاثير الصوديوم إلجينات والصوديوم إلجينات المشعع على إنبات ونمو نباتات الكوكنتا Acokanthera oblongifolia Hochst المشع على إنبات بذور الكوكنتا في المعاملات الأثية(ه جزء في المليون من الصوديوم إلجينات

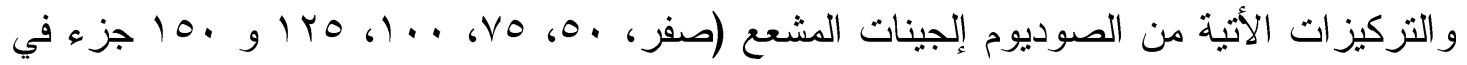

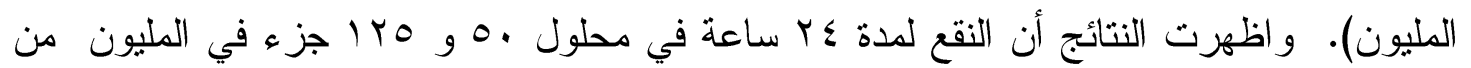
الصوديوم إلجينات المشعع ادي إلى اعلى زيادة في معدل ونسبة الأنبات. التجرية الثانية در اسة تأثير الصوديوم إلجينات و الصوديوم إلجينات المشعع على نمو نباتات الكوكنتا حيث تم رش النباتات بنفس المعاملات المستخدمة في التجرية الأولى و اظهرت النتائج ان استخدام معاملات الصوديوم إلجينات المشعع ادت إلى زيادة في اغلب الصفات المدروسة والمعاملة .0 جزء في المليون من

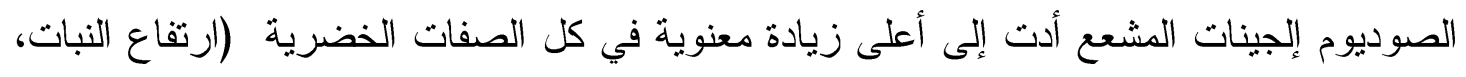
عدد الأوراق، الوزن الطازج و الجاف للنبات، المساحة الورقية، قطر الساق) الصفات الجذرية(حجم الجذور والوزن الجاف للجذور)، محتوى الاوراق من الكلوروفيل ومحتوى النبات من

$$
\text { الكربو هيدر ات. }
$$

